\title{
The Outcry of the Periphery? An Analysis of Ticino's No to Immigration*
}

\author{
Oscar Mazzoleni and Andrea Pilotti \\ Institute of Political, Historical and International Studies, University of Lausanne, \\ Switzerland
}

\begin{abstract}
When the popular initiative "against mass immigration" was accepted by the Swiss people and cantons on 9 February 2014, Ticino had by far the highest approval rate. The Italianspeaking canton thus once more confirmed its singular position, assumed since the 1990s, on popular votes regarding immigration and foreign policy. This seems to be indicative of wider crises and changes in both the economic and political spheres that have favoured the emergence of a political opposition between centre and periphery. The results of a survey among 1400 citizens of Ticino after the vote of 9 February confirm this. In essence, on top of the question of immigration, the vote was influenced by a fearful perception of Ticino as a "double periphery" vis-à-vis both Berne and Lombardy.
\end{abstract}

KeYwords: Ticino, voting behavior, centre-periphery, referendum, regionalism, Switzerland

The Swiss popular initiative "against mass immigration" (accepted on February 9, 2014) is one of the most important votes on migration to take place in the last twenty years. It is significant not only in terms of national relevance and the impact on foreign policy, and in particular with regard to Swiss-EU relations, but also because of regional implications. The highest support for the initiative was seen in Ticino $(68.2 \%$ yes-votes, compared to the national average of $50.3 \%$ ), confirming once again this canton's singularity in referenda related to immigration and foreign policy. Ever since the 1990s, but especially since the 2000 s - as seen when voting, for example, on the bilateral agreements with the EU or on the minaret initiative (see also Manatschal 2015) - Ticino has voted in significant contrast to the national trend. Moreover, the voting behaviour of Ticino over the last two decades also provides for a huge dissimilarity with respect to the tendency of the 1970s and 1980s, when Ticino was recognised for expressing more openness on questions to do with migrants and foreign issues, much like the Frenchspeaking cantons. For example, we observe the lowest support among all Swiss cantons for the first popular initiative on Überfremdung ("excess of foreigners") in 1970, and one of the highest support ratios for the Swiss-European agreements of 1972. By contrast, it was among the cantons most supportive of the fifth Schwarzenbach initiative on the "limitation of immigration", which was put to the vote in 1988, and among the least sympathetic towards the European Economic Area (EEA) agreement in 1992 (Knüsel 1994: 308-312). No other Swiss canton has shown a similar shift during the course of the last forty years.

\footnotetext{
*The authors would like to thank Gian-Andrea Monsch for his support with the data analysis.
} 
Consequently, the question arises how to explain this singularity in federal referenda. In our attempt to respond to it, we will take into account the economic and political evolution and opinions provided by Ticino's citizens. This contribution is organised into three parts: first, we briefly discuss some theoretical perspectives; second, we develop rationales and hypotheses arising from contextual knowledge and previous voting analyses related to Ticino; and third, we highlight some crucial findings from an original cantonal survey devoted to the popular initiative "against mass immigration" in Ticino.

\section{Theoretical reflections}

In trying to explain the voting behaviour in Swiss referenda of the last two decades concerning migration and foreign policy, the dominant trend in the literature has been to focus on the opposition between sovereignty and globalisation, between "conservatism" and "openness" (e.g. Sardi and Widmer 1993; Christin et al. 2002). In this opposition, the main aspects that come into play are the more or less strong attachment to the principles of national independence and the idea of a Swiss "special case" being jeopardized by European integration and immigration (Brunner and Sciarini 2002; Church 2004). Within this perspective, there is also a regional focus, in which the analysis of the perception of foreigners allows a distinction to be made: the French-speaking Swiss seem to have a much more positive perception of French citizens than Swiss-Germans have of Germans (Widmer and Buri 1992; Theiler 2004: 646-650). Moreover, the role of the Swiss People's Party (UDC/SVP) is often mentioned in this perspective because of the leading role it has played and the strategy it has adopted during several referenda related to these issues. Although this opposition also seems to play a crucial role in Ticino, we might ask if this is enough to explain its enduring orientation, which it expresses with a unique strength. Over the last two decades, the greatest differences between Ticino's results and the national average occurred in the referenda on the first bilateral agreements in May 2000 (24.2\%), on the extension of the agreement on the free movement of persons to new EU countries in $2005(19.9 \%)$, and on the initiative against mass immigration in $2014(17.9 \%)$. These outcomes mark clear dissimilarities with respect to both the French- and German-speaking cantons. At the same time, the Swiss People's Party is much weaker in Ticino than it is in other cantons, having gathered only around $6 \%$ of the vote in the last national elections of 2011 (national average: $26.6 \%$ ).

One can consider a second perspective in the literature on voting behaviour, namely one concerning rural-urban opposition (Bolliger 2007). However, as political geographers have pointed out, in recent decades Ticino underwent one of the most radical and intense urbanisation processes of any of the Swiss cantons (Schuler 2009: 130). Moreover, ecological analyses of the voting behaviour in the referendum arena tend to confirm a low salience of rural-urban opposition within this canton (Mazzoleni 2011). Also, in many votes Lugano, the main city of Ticino, clearly appears as an outlier among Swiss cities, because it votes strongly "conservative" in federal referenda (see Hermann \& Leuthold 2003).

A third perspective, finally, is based on an opposition already extensively analysed in comparative political science, namely that between centre and periphery. The latter has only rarely been taken into account in the Swiss literature (however, see Sciarini 2002). Within this theoretical perspective, we may classically consider the concept of peripherality, which is based on the politicisation of remoteness, distinctiveness, and dependence (Rokkan and Urwin 1983). Moreover, we can assume that over the course of recent decades, the loosening of state boundaries has challenged the meaning of the centre- 
periphery opposition, which "is no longer based on the dyadic relationship between the state and the regional distinctive community" (Bartolini 2005: 256). Under globalisation and Europeanization, the framing of the centre-periphery relationship is seen as a political response by structurally weak territories confronting the decline of the national-integrated model established by Keynesian national policies, the weakening of national border control, and higher economic competition among territories. In this sense, the defence of regional interests includes not only self-determination and identity, but also socioeconomic claims (Hepburn 2009). In our theoretical framework, then, the politicisation of peripherality supposes a) structural components, b) a framing discourse by political actors, and c) behaviour and attitudes expressed by citizens that we define as attitudes towards territorial peripherality. In the case of Ticino, several structural and political aspects suggest that this latter perspective can usefully contribute to highlighting the recent voting trend in federal referenda on migration and foreign policy issues.

\section{Troubling a "victorious" periphery}

Although the canton of Ticino in many ways represents an example of a "victorious" region in the European landscape of the twentieth century (Rokkan 1999: 185ff.), a multidimensional crisis - involving socio-economic, identity and political aspects - provides a turning point for Ticino at the beginning of the 1990s. First of all, the most severe economic crisis since the 1930s erupted in the canton. This crisis meant, for the first time in decades, the reappearance of a widespread experience of unemployment for Swiss residents (that is, for voters) in Ticino. To an even greater extent than its socio-economic import, this crisis also had identity implications, since it was accompanied by fears of a decline in the exceptional sense of well-being that the canton had achieved in the period between the 1950s and the 1970s, which had brought an end to a centenary legacy of poverty and emigration. The economic crisis of the early 1990s and its persistence is particularly significant regarding the peripheral status of Ticino among Swiss cantons as it ties in with its insularity, be that in in terms of the economy (historically lower wages than the national average), language (Ticino is the only Swiss canton where Italian - a minority language spoken by about $7 \%$ of Swiss all over the country - is the exclusive official language), or geography (the Alpine chain is a durable obstacle in the relations between Ticino and the rest of Switzerland). Although World War II, the development of the welfare state in Switzerland since the 1940s, and the "thirty glorious years" were able to consolidate the national integration of Ticino, the new global trends embedded in the economic crisis of the 1990s have increased the conditions for peripheral mobilisation by minority nationalisms (Keating and McGarry 2001), including those of borderland regions (Malloy 2010).

In recent decades, therefore, despite the federal system, the style of accommodation, and the institutional recognition of minorities in Switzerland, Ticino seems to have undergone a specific wave of politicisation in terms of the structural components of its peripherality. The economic and cultural crisis of Ticino in the early 1990s overlaps with a significant weakening of those cantonal political parties that traditionally channeled voting behaviour in electoral and referendum arenas. After many decades with a particularly stable cantonal party system (see Vatter 2014), the Christian Democratic Party (PDC/CVP) lost its second seat in the cantonal government in 1987; electoral support for the Liberal Party (PLR/ FDP) has progressively eroded; and the left-wing parties have suffered from strong divisions. It was in this context that a new protest party arose in 1991, the Lega dei Ticinesi, challenging the cantonal party system and, at the same time, the Swiss 
government and parliament by denouncing them for the discriminatory stance they had taken against Ticino - in the past and above all in the present.

In all the cantonal and federal elections since 1991, the Lega has provided several proofs of its electoral achievement. Its apex was achieved with the cantonal elections of 2011, when it became the first party in the cantonal government (with two seats out of five, and about $29 \%$ of voter support), and the second in the cantonal parliament. It was especially supported by unskilled workers and people fearing socio-economic uncertainty (Mazzoleni et al. 2011). What has been crucial in the agenda of the Lega over the last 24 years is the link between regional and national concerns, on the one hand, and between richness and Swissness, on the other. Moreover, as an in-depth diachronic analysis of newspapers (editorials, articles, letters to the editors and advertisements) has shown, the Lega was the main political actor in the federal referendum arena, especially on immigration and foreign policy issues, in the period from 1995 to 2005 (Mazzoleni et al. 2007: 43-44).

However, within the cantonal political system, the Lega does not have a monopoly on centre-periphery claims in the 1990s and 2000s, as expectations towards Berne remained elevated. Especially in the recent years the MPs of almost all the parties in Ticino have submitted several legislative proposals to the federal parliament, including cantonal initiatives. Complaints were heard about the scarcity of Italian-speaking civil servants in the federal administration or among members of the boards of public enterprises (Post, Swisscom, Federal Railways, etc.) and a failure to understand the railway workers' strike of 2008 in Bellinzona - which had exceptionally high support among the population of the whole canton, but also within the cantonal government and political parties from the left to the right - against plans to lay off the workers. We can also refer to the oft-repeated demand, from all cantonal parties, for an Italian-speaking member of the Federal Council, following the resignation of Flavio Cotti in 1999.

The consolidation of centre-periphery claims corresponds to the period comprising the adoption of the agreement with the EU on the free movement of persons in 2002 and the rising number of controversies between Switzerland and Italy in 2008, involving bank account secrecy, the role of the financial place of Lugano, and cross-border workers. Although the concern of cross-border workers also occurs in other parts of Switzerland (Helbling 2011), the politicisation of this issue in Ticino became particularly strong in linking with centre-periphery opposition. A new framing has developed around a "double periphery": the weakening of national borders would increase Ticino's peripherality with respect to the richer Swiss cantons, but also with regard to northern Italy. The growing presence of cross-border workers and persistent socio-economic difficulties in Ticino permit the joining together of claims against both Berne and Italy, Ticino's neighbour and founding member of the EU. This framing emphasises the negative impact of border permeability that increases pressure from the South, since the region of Lombardy (with about 10 million residents) has a higher unemployment rate and lower wages than Ticino (a canton with 350,000 inhabitants). The message is this: an increase in national border permeability means a decrease in Swiss well-being, in particular for Ticino. In the 2000s, the Lega, but also increasingly the centre and right-wing cantonal parties (and, last but not least, the Greens), stressed that increased economic competition enhanced by European integration would represent an authentic risk for regional well-being.

Consequently, in the case of Ticino, with respect to federal referenda on migration and foreign policy issues, the question arises to what extent the national vs. international scheme has to be completed by a centre-periphery frame that informs citizens' attitudes towards peripherality. Empirical evidence shows that this question is far from 
unreasonable, as indicated in the case of the 2005 referendum on the extension of the free movement of persons to the new EU countries, on which a post-referendum survey was carried out among 1,300 Swiss citizens residing in Ticino (Mazzoleni et al. 2007: 113-137). According to this survey, multivariate analyses underline the influence of attitudes regarding foreigners and Swiss neutrality and, above all, the role of trust towards the EU. But what is more - controlling for, among others, age, sex, educational skills, and the perception of economic conditions and political interest - the analysis also shows that the perception of Ticino's relations with Berne and Northern Italy (especially Lombardy), in terms of risks and opportunities, equally exerts a highly relevant impact (Mazzoleni et al. 2007: 134-135).

\section{Attitudes towards peripherality}

More recently, based on a post-vote survey among more than 1,400 citizens, ${ }^{1}$ an analysis of attitudes and behaviour on the occasion of the vote on the popular initiative "against mass immigration" in Ticino confirms the impact of the opposition between "national sovereignty" and "international openness", but also - and at the same time - that of the centre-periphery dimension (Pilotti and Mazzoleni 2014). Let us now present these findings in more detail.

First of all, the survey allows for answers to an open question about subjective motivations when voting on the initiative "against mass immigration". Thus, $29.8 \%$ of all answers emphasise the "need to regulate immigration that is out of control", while $42 \%$ mention an economic motivation related to the regional labour market. More particularly, $21.3 \%$ denounce that "too many cross-border workers create unemployment, illicit competition in the labour market and traffic jams"; $11.1 \%$ want priority to be given to Swiss and Ticino citizens in the labour market; and $10.3 \%$ point to declining income and rising unemployment, highlighting the link between feelings of (in)tolerance toward immigrants and the fear of losing economic wealth (see also Freitag and Rapp 2013). Finally, $11.4 \%$ wanted to send a message to the political authorities as "unheard citizens". In contrast, $20.1 \%$ of opponents declare themselves to be aware of the "problems" but claim the initiative is inadequate; $19.6 \%$ argue the initiative is "too extreme"; and $14.1 \%$ regard immigrants as an opportunity for Switzerland (for more details, see Pilotti and Mazzoleni 2014: 40). These answers to the open question suggest that immigration is the dominant aspect for the initiative's supporters, but also that there are other dimensions connected to the anti-establishment protest and the specific socioeconomic situation of Ticino as a borderland and periphery. More particularly, it is difficult to disarticulate issues related to the national scale from those concerning the regional scale.

In an attempt to show the impact of specific regional issues, our perspective proceeds to highlight attitudes towards peripherality with a set of items and their link to voting behaviour. $^{2}$ Table 1 shows that the initiative's supporters explicitly refer to Ticino as a "special case" claiming support from the Swiss Confederation. A very high proportion of those who fully agree that "Switzerland should do more for the Canton of Ticino" and "the Canton of Ticino has a greater need to defend itself from foreign competition than

\footnotetext{
${ }^{1}$ This survey was carried out between 9 February and 3 March 2014.

${ }^{2}$ With regards to the difficulties inherent in measurement equivalence among subnational groups, including Switzerland (Sarrasin et al. 2013), we prefer to adopt a closely context-dependent set of items.
} 
Table 1: Vote on the initiative "against mass immigration" and attitudes on peripherality (part 1) in Ticino, in $\%^{1}$

\begin{tabular}{|c|c|c|c|c|c|c|}
\hline & Yes & No & Total & $\mathrm{N}$ & p-Chi $2^{2}$ & Cramer's V \\
\hline Switzerland should do more for Ticino & & & & & $* * *$ & $0,309 * * *$ \\
\hline Strongly disagree & 39.5 & 60.5 & 100.0 & 38 & & \\
\hline Somewhat agree & 50.6 & 49.4 & 100.0 & 342 & & \\
\hline Strongly agree & 79.4 & 20.6 & 100.0 & 778 & & \\
\hline Total & 69.6 & 30.4 & 100.0 & 1158 & & \\
\hline $\begin{array}{l}\text { Ticino has a greater need to defend itself against } \\
\text { foreign competition than other Swiss regions }\end{array}$ & & & & & $* * *$ & $0,289 * * *$ \\
\hline Strongly disagree & 44.4 & 55.6 & 100.0 & 99 & & \\
\hline Somewhat agree & 55.9 & 44.1 & 100.0 & 329 & & \\
\hline Strongly agree & 80.3 & 19.7 & 100.0 & 692 & & \\
\hline I don't know/NR & 61.4 & 38.6 & 100.0 & 57 & & \\
\hline Total & 69.6 & 30.4 & 100.0 & 1177 & & \\
\hline $\begin{array}{l}\text { Ticino must achieve more by itself and rely } \\
\text { less on support from the Swiss Confederation }\end{array}$ & & & & & $*$ & $0,087 *$ \\
\hline Strongly disagree & 78.6 & 21.4 & 100.0 & 206 & & \\
\hline Somewhat agree & 67.7 & 32.3 & 100.0 & 502 & & \\
\hline Strongly agree & 69.5 & 30.5 & 100.0 & 419 & & \\
\hline Total & 70.4 & 29.6 & 100.0 & 1127 & & \\
\hline
\end{tabular}

1 "I don't know/no response" is shown only if the percentage is higher than $5 \%$.

${ }^{2}$ n.s. $=$ not significant; $*=p<0.05 ; * *=p<0.01 ; * * *=p<0.001$.

Source: Research Observatory for Regional Politics, University of Lausanne (Ovpr-Unil), 2014.

other Swiss regions" supported the initiative (79.4\% and $80.3 \%$, respectively). The proportion of supporters markedly decreases among those (few) who do not agree with these statements (39.5\% and $44.4 \%$, respectively). Unexpectedly, our indicator of cantonal "entrepreneurship" seems not to exert direct influence on the voting behaviour. The relationship between voting behaviour and the statement "Ticino must achieve more by itself and rely less on support from the Confederation" appears marginal.

Table 2 adds three other indicators of peripherality. Those who supported the initiative believe almost unanimously that tighter relations with the European Union threatens the identity of Ticino (93.3\%), while on the other side, the proportion of the initiative's supporters strongly decreases among those who agree only a little or not at all with this assertion (32.4\%). Moreover, supporters are opposed to a greater economic integration of Ticino with Lombardy (89.5\%) and to a strengthening of relations with Italy $(86.7 \%)$. Conversely, a majority of those who oppose the initiative "against mass immigration" agree very much with the assertions that "the Canton of Ticino has to take advantage of an economic integration with Lombardy" (58.4\%) and that, "as a linguistic minority, Ticino has everything to gain in strengthening its relations with Italy" $(60.6 \%)$.

These indicators tend to show that the dual relationship, with Berne on the one hand and with Italy (and especially Lombardy) on the other, has had an influence on voting in the initiative "against mass immigration". Feelings of discrimination ("the Canton of Ticino has a greater need to defend itself from foreign competition than other Swiss regions"); fears of Europeanization ("Tighter relations with the European Union will threaten the identity of Ticino") and economic trans-border integration ("Ticino has to 
Table 2: Vote for the initiative "against mass immigration" and attitudes on peripherality (part 2) in Ticino, in $\%{ }^{1}$

\begin{tabular}{|c|c|c|c|c|c|c|}
\hline & Yes & No & Total & $\mathrm{N}$ & p-Chi $2^{2}$ & Cramer's V \\
\hline $\begin{array}{l}\text { Ticino has to take advantage of } \\
\text { economic integration with Lombardy }\end{array}$ & & & & & $* * *$ & $0,353 * * *$ \\
\hline Strongly disagree & 89.5 & 10.5 & 100.0 & 334 & & \\
\hline Somewhat agree & 70.1 & 29.9 & 100.0 & 532 & & \\
\hline Strongly agree & 41.6 & 58.4 & 100.0 & 214 & & \\
\hline I don't know/NR & 61.2 & 38.8 & 100.0 & 85 & & \\
\hline Total & 69.8 & 30.2 & 100.0 & 1165 & & \\
\hline $\begin{array}{l}\text { As a linguistic minority, Ticino has everything } \\
\text { to gain in strengthening its relations with Italy }\end{array}$ & & & & & $* * *$ & $0,334 * * *$ \\
\hline Strongly disagree & 86.7 & 13.3 & 100.0 & 392 & & \\
\hline Somewhat agree & 67.6 & 32.4 & 100.0 & 578 & & \\
\hline Strongly agree & 39.4 & 60.6 & 100.0 & 160 & & \\
\hline Total & 70.3 & 29.7 & 100.0 & 1130 & & \\
\hline $\begin{array}{l}\text { Tighter relations with the European Union } \\
\text { will threaten the identity of Ticino }\end{array}$ & & & & & $* * *$ & $0,512 * * *$ \\
\hline Strongly disagree & 32.4 & 67.6 & 100.0 & 281 & & \\
\hline Somewhat agree & 71.9 & 28.1 & 100.0 & 431 & & \\
\hline Strongly agree & 93.3 & 6.7 & 100.0 & 402 & & \\
\hline Total & 69.7 & 30.3 & 100.0 & 1114 & & \\
\hline
\end{tabular}

1 "I don't know/no response" is shown only if the percentage is higher than $5 \%$.

2 n.s. $=$ not significant; $*=p<0.05 ; * *=p<0.01 ; * * *=p<0.001$.

Source: Research Observatory for Regional Politics, University of Lausanne (Ovpr-Unil), 2014.

take advantage of economic integration with Lombardy"); plus claims for national protection ("Switzerland should do more for Ticino") appear to be strongly related to each other ${ }^{3}$ and to the vote itself.

Next, helped by multivariate models (logistic regression), we ask whether - beyond some other factors such as issues of immigration and those related to political authorities (strongly linked to the motivations mentioned by the respondents in the open question) there is a specific impact of attitudes towards peripherality. In preliminary models (see Table 3), we can observe the impact of socio-professional variables, political trust (towards the federal government, the EU, and Ticino politicians), and aspects related to the perception of immigrants' presence in Switzerland, in general, as well as immigrants' impact on the economic well-being on a national scale, in particular. ${ }^{4}$ As expected, the analysis shows a contrast between the national and European scale, on the one hand, and Ticino, on the other: lower trust in the federal government and the European Union increases the probability of support for the initiative. Inversely, it is higher trust in the

\footnotetext{
${ }^{3}$ For instance, "Switzerland should do more for Ticino" is strongly correlated with "Tighter relations with the European Union will threaten the identity of Ticino" $\left(0.385^{* * *}\right.$ Cramer's V) and "Ticino has to take advantage of economic integration with Lombardy" (0.293*** Cramer's V).

${ }^{4}$ Two items are considered. We ask the respondents if they agree more or less (on a 7-point scale) with the statements "In Switzerland, there are too many immigrants" and "Swiss well-being is also dependent on the contribution of foreigners". With these two items, and with the question of trust in the EU, we also capture the opposition between "conservatism" and "openness".
} 


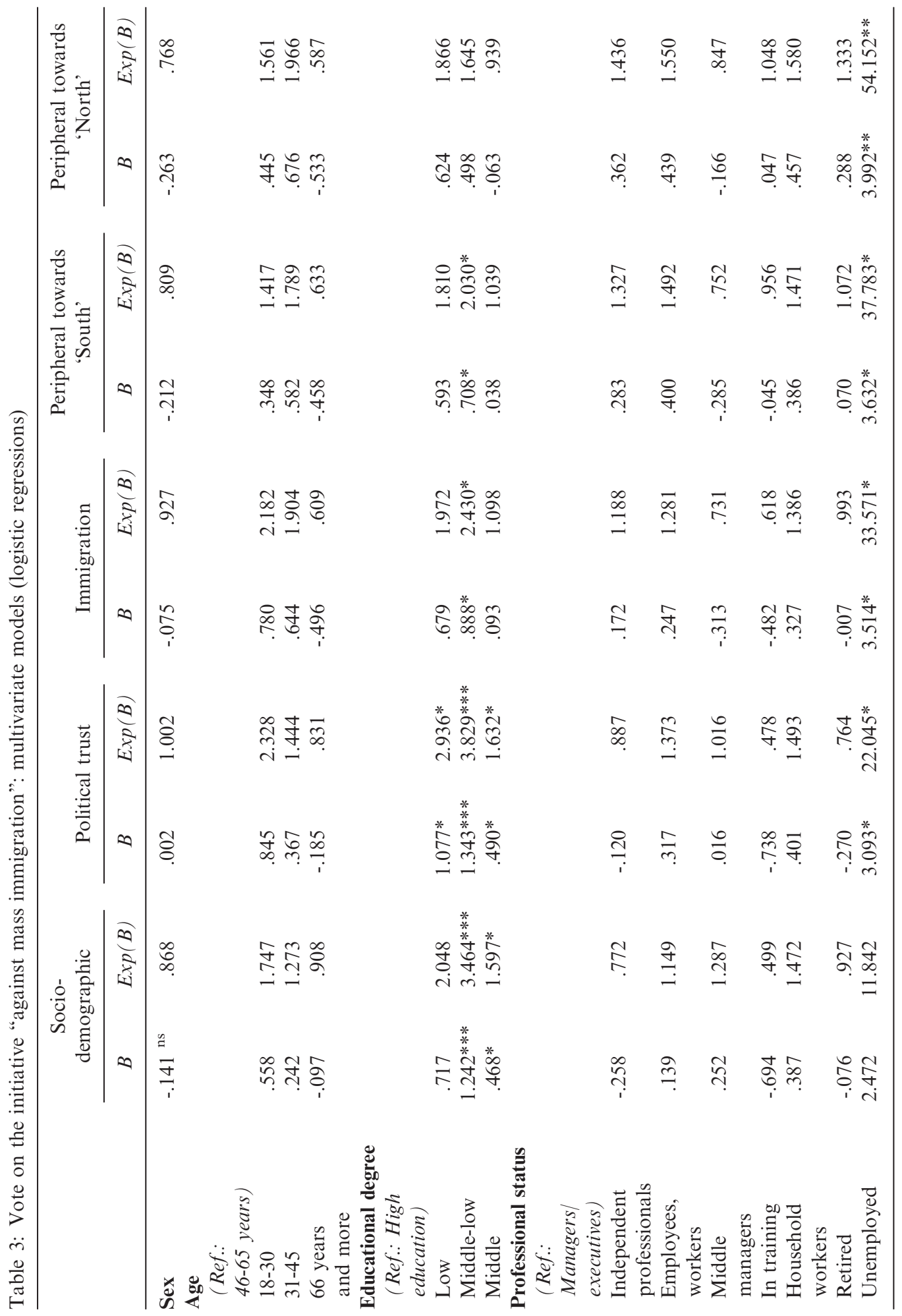




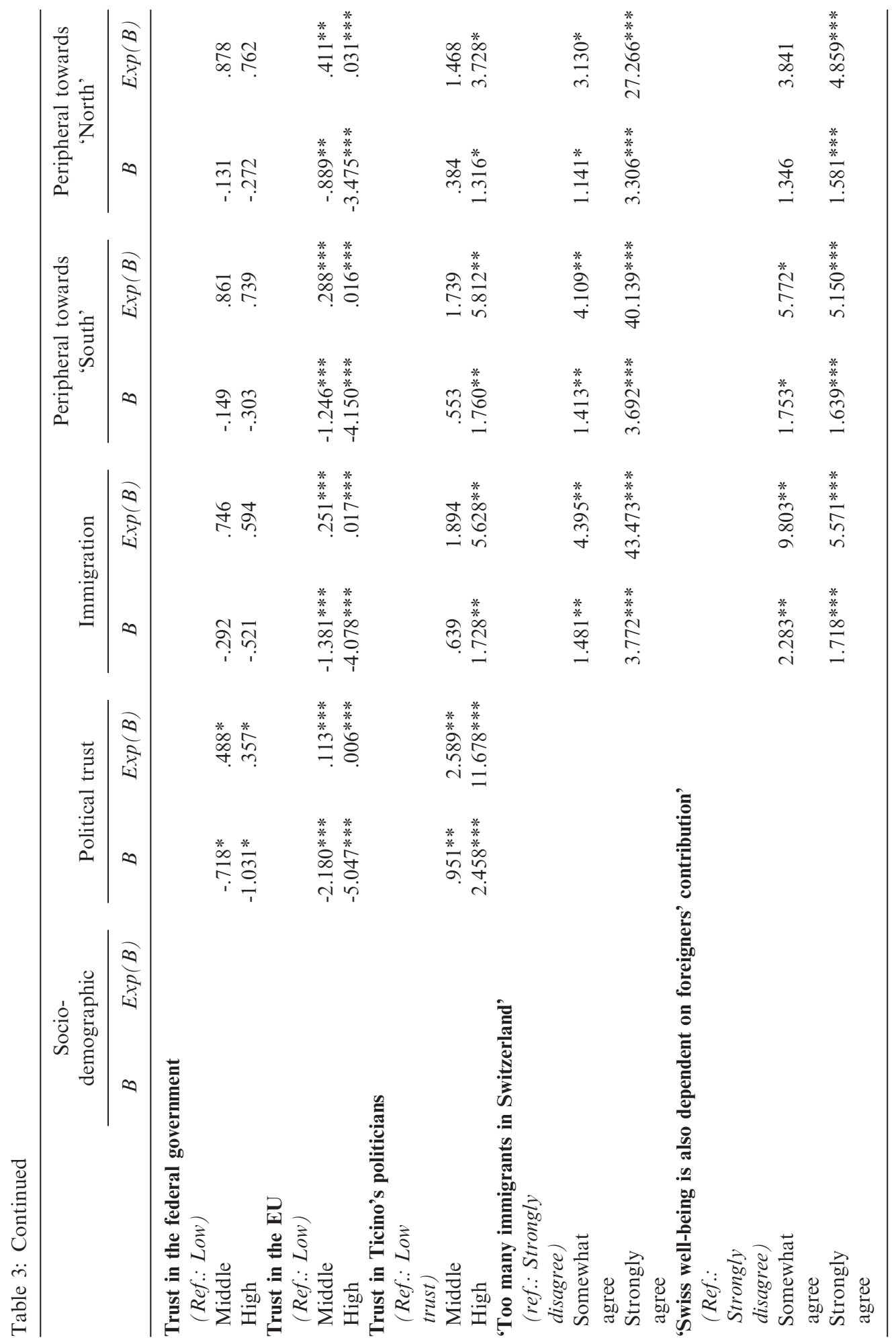




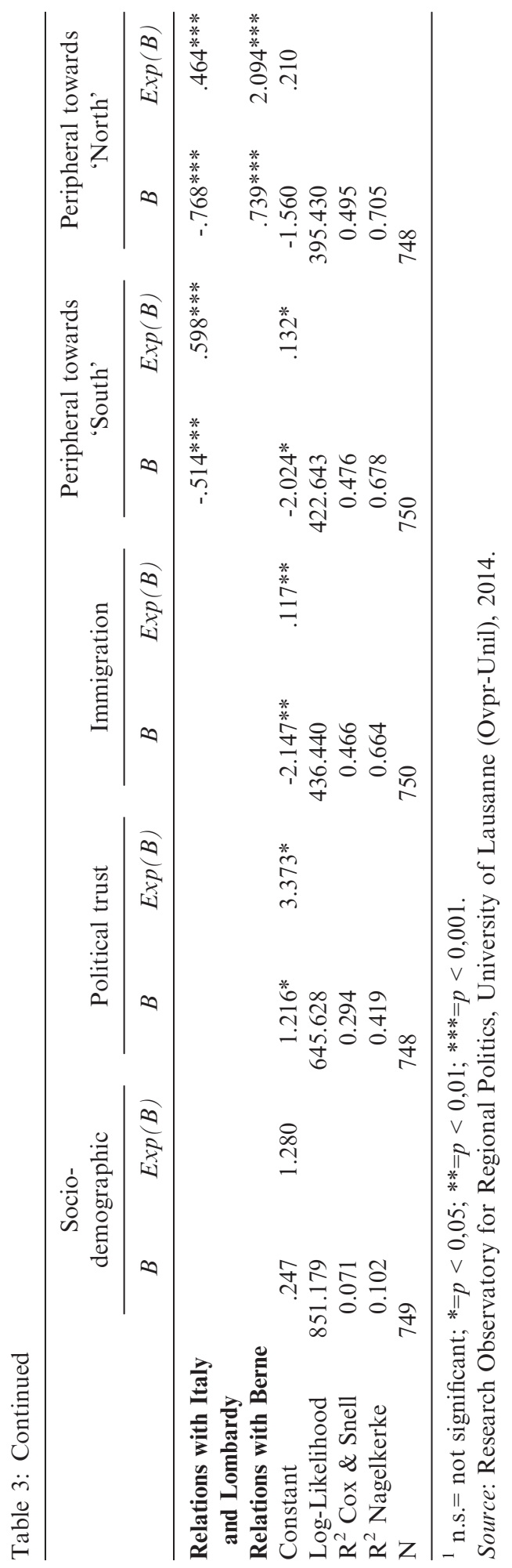


politicians of Ticino that tends to be positively related to supporting the initiative. This result seems to introduce an explicit political component into the attitudes towards peripherality, giving a specific position to the cantonal political elites.

Finally, in the last multivariate models we add a synthesis of items related to peripherality through two components provided by an exploratory factor analysis, one related to the Italian component (Italy and Lombardy), the other to Berne and its 'open' foreign policy (feelings of discrimination by comparison to other regions and national protection), whilst the link with the EU overlaps the two components. ${ }^{5}$ Our indicator of "cantonal entrepreneurship" ("Ticino must achieve more by itself and rely less on support from the Confederation") is only very weakly correlated with the other variables and for this reason excluded from the factor analysis, contrasting with the outcome of the analysis of 2005 (Mazzoleni et al. 2007: 132) in which cantonal "entrepreneurship" was significantly correlated to the indicators of closeness to Italy and Lombardy.

However, as this last multivariate model confirms, all else being equal, both components of the attitudes towards peripherality significantly explain the probability of supporting or opposing the initiative on 9 February 2014. Relevant are, on the one hand, the different perceptions of Ticino as a vulnerable periphery needing federal protection. On the other hand, there is also a different judgement concerning the importance for the Italianspeaking canton to have a proactive attitude and to be dynamic vis-à-vis Italy, in general, and Lombardy, in particular.

\section{Conclusions}

Our exploration devoted to the enduring orientation of Canton of Ticino with regard to immigration and foreign-policy issues over the last 25 years has tried to explain this not only as an opposition between national "conservatism" and international "openness", but also in terms of centre-periphery opposition. Socio-economic and cultural crises as well as political changes have favoured the emergence of this phenomenon in Ticino ever since the beginning of the 1990s, expressed in turn through a new mobilisation within this canton thanks to the presence and success of a regionalist party, the Lega dei Ticinesi. In the 2000s, the impact of processes related to Europeanisation and globalisation further enhanced the relevance of centre-periphery politicisation in Ticino, reinforcing and enlarging the "national" centre-periphery claim with a trans-border and transnational centre-periphery protest with regards to increasing and durable fiscal controversies between Switzerland (Ticino) and Italy.

In this configuration, federal referenda on immigration and foreign policy have become channels in which these claims can be expressed. Territorially bounded attitudes not only entail feelings against foreign policy openness and immigration in general, but also assume meanings related to centre-periphery opposition. A first cantonal survey carried out in 2005 about the extension of the agreement on the free movement of persons with the EU confirmed the impact of attitudes of peripherality on voting behaviour in Ticino. A second cantonal survey, focused once again on Ticino but this time regarding the initiative "against mass immigration" voted and accepted on 9 February 2014, equally confirms, as we have highlighted in this contribution, the impact of attitudes of peripherality, towards

\footnotetext{
${ }^{5}$ Two factors are provided by an exploratory maximum-likelihood factor analysis with seven variables presented in tables 1 and 2 (rotation varimax, $44.5 \%$ variation explained).
} 
both Berne and Italy. As we have also shown, support for the initiative of 9 February is far from being an anti-establishment protest, but instead entails trust in regional politicians.

Of course, this does not mean that all federal referenda devoted to immigration and foreign policy must show this result, but a perspective based on centre-periphery opposition may also be crucial for understanding many other mobilisations in which Ticino represents an outlier from national trends. At the same time, this perspective might not only be helpful to explain - at least partially - voting behaviour in the case of Ticino. In Switzerland, too, the acceleration of the European integration process seems to coincide, on the one hand, with deep socio-economic changes and, on the other, with a redefinition of centre-periphery relations. In the case of Ticino, important consequences of these evolutions are durable centre-periphery party mobilisations and enduring predispositions in federal referenda. In any case, it would be useful to consider more carefully the impact of the context-dependent implications of the "conservation" vs. "openness" opposition in all parts of Switzerland, since these may vary between regions and cantons.

\section{References}

Bartolini, S. (2005). Restructuring Europe. Centre formation, system building, and political structuring between the nation State and the European Union. Oxford: Oxford University Press.

Bolliger, C. (2007). Konkordanz und Konfliktlinien in der Schweiz: 1945 bis 2003. Parteienkooperation, Konfliktdimensionen und gesellschaftliche Polarisierungen bei den eidgenössischen Volksabstimmungen. Bern: Haupt Verlag.

Brunner, M. and P. Sciarini (2002). L'opposition ouverture-tradition. In Hug, S. and P. Sciarini (eds.), Changements de valeurs et nouveaux clivages politiques en Suisse. Paris: L'Harmattan (2993).

Christin, T., S. Hug and P. Sciarini (2002). La mobilisation des clivages lors des votations populaires. In Hug, S. and P. Sciarini (eds.), Changements de valeurs et nouveaux clivages politiques en Suisse. Paris: L'Harmattan (237-267).

Church, C. H. (2004). Swiss Euroscepticism: Local Variations on wider Themes. In Harmsen, R. and M. Spiering M. (eds.), Euroscepticism, Party Politics, National Identity and European Integration. Amsterdam: European studies (269-290).

Freitag, M. and C. Rapp (2013). Intolerance Toward Immigrants in Switzerland: Diminished Threat Through Social Contacts? Swiss Political Science Review 19(4): 425-446.

Helbling, M. (2011). Why Swiss-Germans dislike Germans. Opposition to culturally similar and highly skilled Immigrants. European Societies 13(1): 5-27.

Hepburn, E. (2009). Introduction: Re-conceptualizing Sub-state Mobilization. Regional and Federal Studies 19(4/5): 477-499

Hermann, M. and H. Leuthold (2003). Atlas der politischen Landschaften: ein weltanschauliches Porträt der Schweiz?. Zurich: vdf Hochschulverlag

Keating, M. and J. McGarry (2001). Minority Nationalism and the Changing International Order. Oxford: Oxford University Press.

Knüsel, R. (1994). Plurilinguisme et enjeux politiques. Les minorités ethnolinguistiques autochtones à territoires: l'exemple du cas helvétique. Lausanne: Payot.

Malloy, H.T. (2010). Creating New Spaces for Politics? The Role of National Minorities in Building Capacity of Cross-border Regions. Regional and Federal Studies 20(3): 335-351. 
Manatschal, A. (2015). Switzerland - Really Europe's heart of darkness? Swiss Political Science Review 21(1): 23-35.

Mazzoleni, O. (2011). Le vote sur les questions migratoires dans le canton du Tessin. Tangram 28 ('Ville-Campagne'): 53-55.

Mazzoleni, O., P. Ferragutti, M. Stanga and A. Pilotti (2007). L'Europa vista dal Ticino. Campagne e voto referendario. Bellinzona: Ustat.

Mazzoleni, O., M. Pacella and A. Plata (2011). Le elezioni cantonali ticinesi del 2011. Partecipazione e orientamento di voto fra lealtà, defezione, protesta. Lausanne: Travaux de science politique, Université de Lausanne.

Pilotti, A. and O. Mazzoleni (2014). Il voto ticinese sull'iniziativa «contro l'immigrazione di massa» del 9 febbraio 2014. Lausanne: Travaux de science politique, Université de Lausanne.

Rokkan, S. (1999). State formation, Nation-Building and Mass Politics in Europe. The Theory of Stein Rokkan. Oxford: Oxford University Press.

Rokkan, S. and W.D. Urwin (1983). Economy, territory and Identity. Politics of West European Peripheries. London: Sage.

Sardi, M. and E. Widmer (1993). L'orientation du vote. In Kriesi, H. (ed), Citoyenneté et démocratie directe. Compétence, participation et décision des citoyens et citoyennes suisses. Zurich: Seismo (191-212).

Sarrasin, O., E.G.T. Green, A. Berchtold and E. Davidov (2013). Measurement Equivalence across Subnational Groups: An Analysis of the Conception of Nationhood in Switzerland. International Journal of Public Opinion Research 25(4): 522-534.

Schuler, M. (2009). La Svizzera italiana fra perifericità e centralità. In Mazzoleni, O. and R. Ratti (eds.), Identità nella globalità. Le sfide della Svizzera italiana. Lugano: Casagrande (121-131).

Sciarini, P. (2002). L'opposition centre-périphérie. In Hug, S. and P. Sciarini (eds.), Changements de valeurs et nouveaux clivages politiques en Suisse. Paris: L'Harmattan (179-206).

Theiler, T. (2004). The origins of Euroscepticism in German-speaking Switzerland. European Journal of Political Research 43(4): 635-656.

Vatter, A. (2014). Das politische System der Schweiz. Baden-Baden: Nomos.

Widmer, T. and C. Buri (1992). Brüssel oder Bern: schägt das Herz der "Romands" eher für Europa? Ein Vergleich der Einstellungen von Deutsch- und Westschweizerinnenn zur EuropaFrage. Schweizerisches Jahrbuch für Politische Wissenschaft 32: 363-387.

Oscar Mazzoleni, Institute of Political, Historical and International Studies, Géopolis Building, University of Lausanne, 1015 Lausanne, Switzerland; Email: oscar.mazzoleni@unil.ch.

Andrea Pilotti, Institute of Political, Historical and International Studies, Géopolis Building, University of Lausanne, 1015 Lausanne, Switzerland; Email: andrea.pilotti@unil.ch. 